\title{
Kesetaraan Program Arsitektur berdasarkan Aktivitas Manusia
}

\author{
Multazam Akbar Junaedi dan Defry Agatha Ardianta \\ Departemen Arsitektur, Fakultas Arsitektur, Desain dan Perencanaan, \\ Institut Teknologi Sepuluh Nopember (ITS) \\ e-mail: agathadefry@arch.its.ac.id
}

\begin{abstract}
Abstrak-Arsitektur dalam sebuah sistem fungsi sosial seharusnya memikirkan setiap irisan dari segala sistem yang ada dalam lingkungan. Sehingga seharusnya dalam ilmu arsitektur tidak ada hierarki desain dalam rancangan bangunan arsitektur. Dengan pembacaan tersebut permasalahan yang diangkat adalah diferensial lingkungan sosial dalam aspek fisik dan non-fisik pada koridor Tunjungan, Surabaya. Pendekatan Arsitektur dan Perilaku Manusia, menjadi kacamata analisa masalah pada konteks lingkungan dan sosial. Variabel waktu dan kepemilikan ruang di definisikan sebagai acuan dalam menentukan program yang akan dirancang. Sehingga pergerakan penduduk dan nonpenduduk Tunjungan dirasa cukup mewakili masalah fisik maupun non-fisik pada konteks, yang kemudian digunakan sebagai dasar olahan formal dan teknis pada rancangan arsitektur. Konsep Equality and No-Segmentation menjadi konsep besar yang digunakan dalam rancangan arsitektur. Memberikan kesetaraan pada subjek penduduk dan nonpenduduk Tunjungan dalam kepemilikan ruang di konteks rancang. Sehingga tidak ada lagi kesenjangan desain dalam program arsitektur antara manusia, yaitu penduduk dan nonpenduduk di Koridor Tunjungan, Surabaya.
\end{abstract}

Kata Kunci-Fungsi Sosial, Kesetaraan, Lingkungan Fisik dan Sosial, Aktivitas Manusia, Pergerakan Manusia, Segmentasi.

\section{PENDAHULUAN}

$\mathrm{R}$ ANCANGAN arsitektur erat kaitannya dengan manusia sebagai subjek, dan lingkungan sebagai latar dari sebuah desain. Ketika arsitektur terdefinisi sebagai wadah dari sebuah aktivitas manusia, maka arsitektur akan terbentuk oleh manusia itu sendiri. Sehingga pada proses perancangan arsitektur, akan membahas tentang bagaimana manusia itu beraktivitas yang kemudian di terjemahkan pada bahasa program arsitektur. Program dan aktivitas sering kali menjadi bahasa yang tepat dalam mengategorikan fungsi-fungsi yang akan hadir dalam sebuah desain rancangan arsitektur. (Gambar 1)

Manusia adalah variabel tidak tetap yang berbeda satu sama lain dalam berbagai aspek. Sehingga satu lingkungan dengan lingkungan yang lain akan mempunyai karakteristik yang berbeda jika variabel yang ditinjau adalah manusia. Maka dari itu, konteks desain menjadi penting ketika rancangan desain akan hadir untuk sebuah lingkungan. Ketika arsitektur adalah sebagai wadah dari aktivitas manusia, maka arsitektur tidak pernah akan sama pada lingkungan yang berbeda (Tabel 1) [1].

Dalam buku "The Autopoiesis of Architecture" pada bahasan "Societal Function", [2] Patrik Schumacher membahas tentang bagaimana dalam sebuah lingkungan masyarakat terdapat tingkatan yang berbeda-beda. Konsepsi

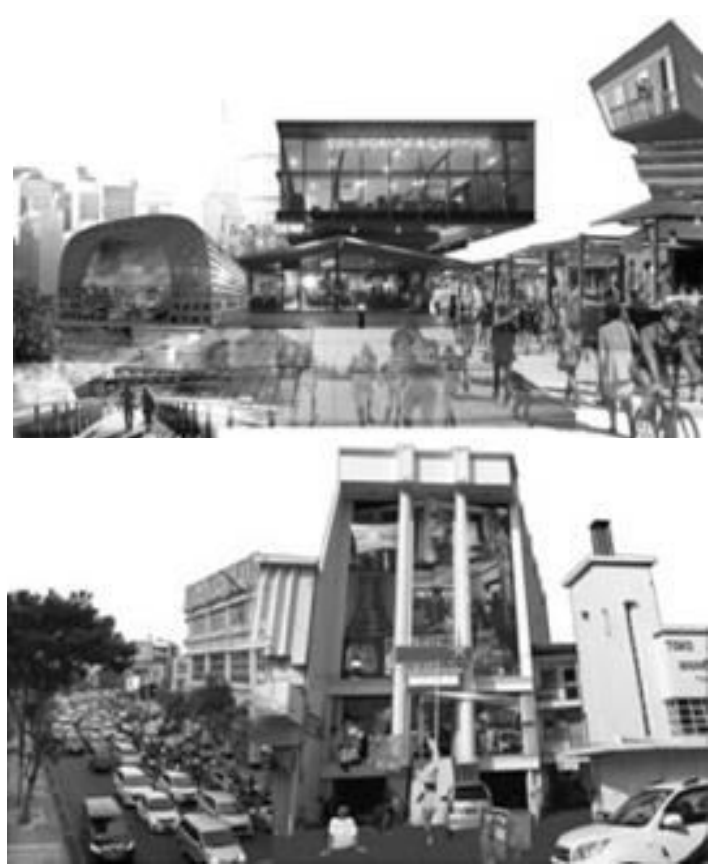

Gambar 1. Keberagaman Aktivitas Manusia.

Tabel 1.

Inventaris Pola Aktivitas Manusia

\begin{tabular}{|l|l|l|}
\hline Aktivitas & Interest & Opini \\
\hline Bekerja & Keluarga & Diri mereka sendiri \\
\hline Hobi & Rumah & Masalah-masalah sosial \\
\hline Peristiwa sosial & Pekerjaan & Politik \\
\hline Liburan & Komunitas & Bisnis \\
\hline Hiburan & Rekreasi & Ekonomi \\
\hline Anggota Klub & Pakaianyjy & Pendidikan \\
\hline Komunitas & Makanan & Produk \\
\hline Belanja & Media & Masa depan \\
\hline Olahraga & Prestasi & Budaya \\
\hline
\end{tabular}

Sumber: Plummer, 1997

"level" dalam artian luas, bisa jadi secara harfiah seperti garis vertikal yang mempunyai tingkatan, ataupun diterjemahkan dalam kondisi nyata yaitu lingkungan masyarakat dengan manusia yang tidak akan sama satu terhadap manusia lainnya. Ketika manusia dalam suatu lingkungan memiliki tingkatan yang berbeda, maka secara sederhana manusia tersebut memiliki karakteristik yang berbeda. Begitu pula dengan preferensi mereka terhadap sesuatu akan berbeda-beda satu sama lain. Terlebih lagi jika membahas tentang gaya hidup manusia dalam lingkungan, akan berbeda pula. Maka, pertanyaan besar yang muncul dari fakta dan gagasan di atas 
adalah "Bagaimana arsitektur yang tepat guna dan tepat

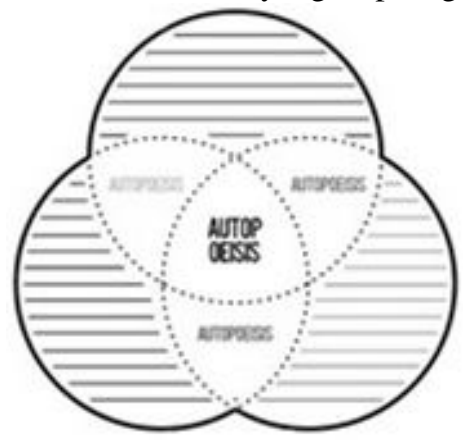

Gambar 2. Diagram Pemahaman Arsitektur Autopoiesis.

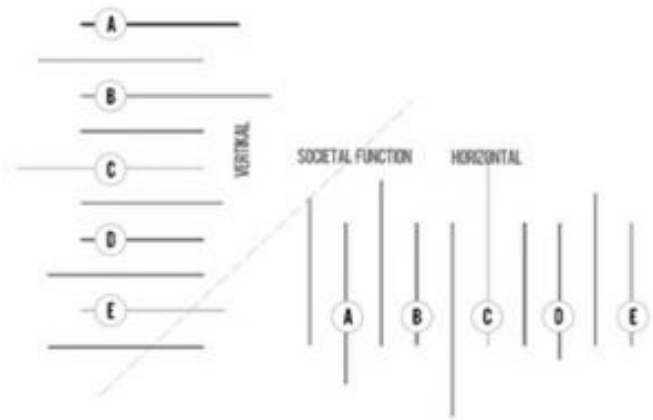

Gambar 3. Diagram Arsitektur Autopoiesis, Societal Function.

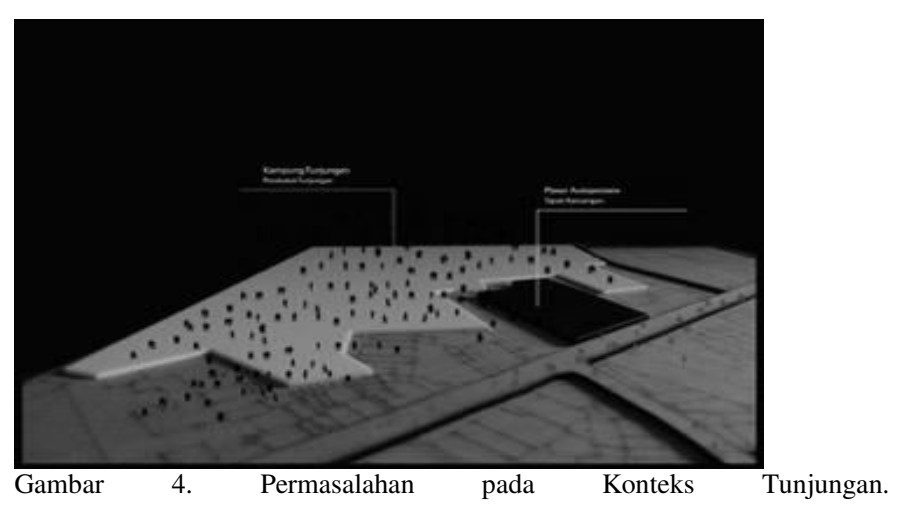

Ketika arsitektur melibatkan manusia sebagai sistem dalam rancangan, seharusnya program arsitektur tidak boleh dominan pada salah satu variabel karena keberagamannya. Sehingga sesuai dengan literatur yang terdapat pada buku "The Autopoiesis of Architecture", dalam menentukan program arsitektur pada sistem yang beragam, seharusnya yang dilakukan untuk mencapai kesetaraan adalah mempertimbangkan rencana yang dilakukan pada setiap irisan sistemnya. Sehingga dalam perencanaan program arsitektur, manusia sebagai sistem seharusnya memiliki kesetaraan dan tidak ada yang lebih diuntungkan maupun dirugikan dalam berbagai aspek fisik maupun non fisik (Gambar 2).

Dalam hal yang lebih nyata lagi seperti yang dijelaskan dalam subbab "Societal Function" menjelaskan bagaimana seharusnya berpikir kesetaraan dalam proses kehidupan masyarakat di sebuah lingkungan sosial. Ketika fenomenanya adalah terdapat fungsi sosial yang tergambarkan dengan "vertikal" dalam pemikiran arsitektur autopoiesis fenomena tersebut harus di "horizontal"-kan. Seperti dalam sebuah lingkungan sosial terdapat variabel masing-masing masalah sasaran dalam sebuah lingkungan masyarakat sosial?".

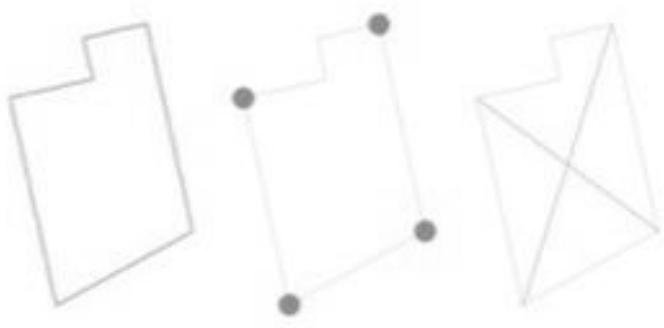

Gambar 5. Titik Kesetaraan.

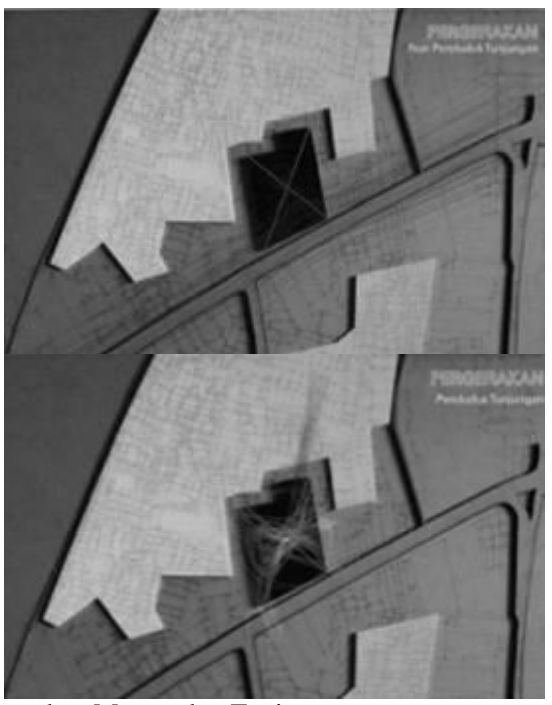

Gambar 6. Pergerakan Masyarakat Tunjungan.
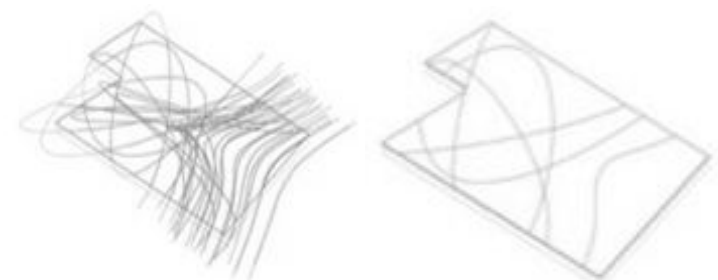

Gambar 7. Menyederhanakan Garis Implikasi Pergerakan.

sosial, fenomena yang terjadi adalah variabel tersebut tersusun berdasarkan tingkatan vertikal. Fenomena tersebut secara tidak langsung memunculkan fungsi sosial berdasarkan levelnya. Namun dalam arsitektur autopoiesis, variabel tersebut harusnya disusun secara setara dengan tingkatan yang sama dan berbentuk horizontal. Setiap variabelnya mempunyai otonomnya sendiri namun tetap dalam satu garis. Fokusan arsitektur autopoiesis dalam fungsi sosial adalah bagaimana meng-eksklusifkan setiap variabelnya, serta memikirkan garis di setiap variabel sebagai penghubung perbedaan otonom dan harus tetap berjalan dengan baik sesuai dengan prinsip kesetaraan yang diilustrasikan dengan bentuk horizontal (Gambar 3).

Koridor Tunjungan adalah salah satu konteks yang memiliki fenomena keberagaman aktivitas, preferensi, dan gaya hidup pada masyarakatnya [3] terdapat permasalahan antara penduduk Tunjungan dengan non-penduduk Tunjungan. Terjadi diferensial pada lingkungan fisik dan sosial, dimana seolah koridor Tunjungan hanya digunakan oleh non-penduduk saja (merah). Begitu juga yang terjadi 


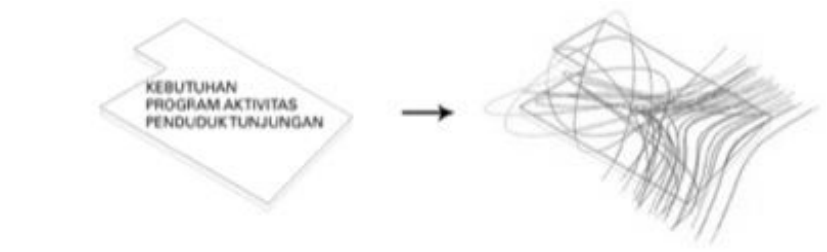

Gambar 8. Perletakan Program Berdasarkan Garis Pergerakan.
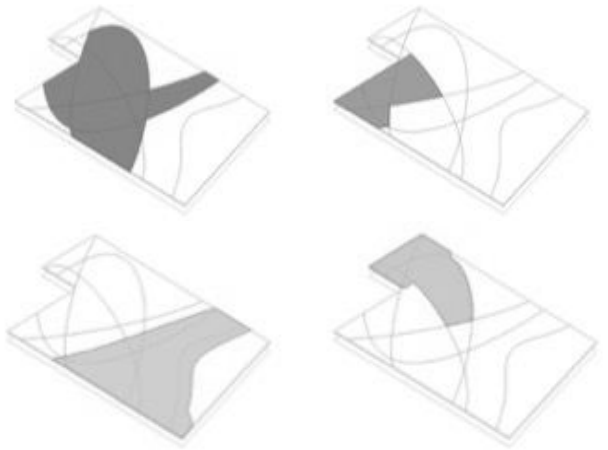

Gambar 7. Program dan Aktivitas Primer-Sekunder.

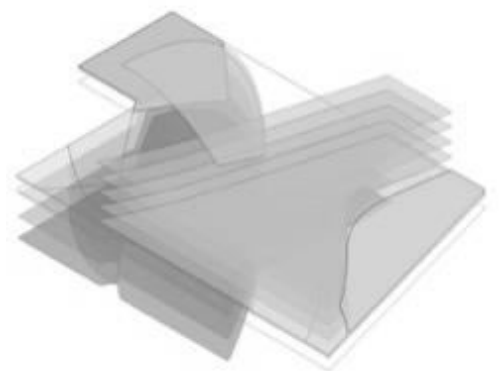

Gambar 10. Elevasi Platform.

pada kampung-kampung di dalam segitiga Tunjungan seolah hanya tidak merasa memiliki koridor tunjungan (hitam). Padahal sejatinya kedua subjek tersebut seharusnya setara dalam tingkatan sosial dalam memiliki dan menggunakan koridor Tunjungan. Sehingga dapat disimpulkan bahwa permasalah yang terjadi pada konteks lingkungan fisik dan sosial adalah bagaimana koridor Tunjungan seolah hanya dimiliki dan digunakan oleh non-penduduk Tunjungan saja. Dengan kata lain berdasarkan pembacaan lingkungan fisik dan sosial sesuai dengan isu arsitektural, masalah yang terjadi pada konteks lingkungan fisik dan sosial tersebut adalah terdapat permasalahan diferensial gaya hidup masyarakat Tunjungan, dan terjadi permasalahan kesetaraan antara penduduk Tunjungan dan non-penduduk Tunjungan (Gambar 4).

\section{METODA PERANCANGAN}

Metode konseptual dalam perancngan ini adalah teori yang menjadi landasan berpikir dalam kesetaraan program arsitektur yaitu teori "The Autopoiesis of Architecture". Landasan berpikir tersebut di terjemahkan dalam langkahlangkah yang dapat mewakili proses berpikir desain dalam metode perancangan:

1. Titik Kesetaraan (Gambar 5 ): Metode titik kesetaraan adalah bertujuan untuk mencari titik konsepsi dari bidang tapak. Untuk mencari titik kesetaraan dalam bidang tapak, hal yang dilakukan adalah mencari titik-titik paling luar dari bidang tapak. Kemudian mempertemukan titik-titik tersebut

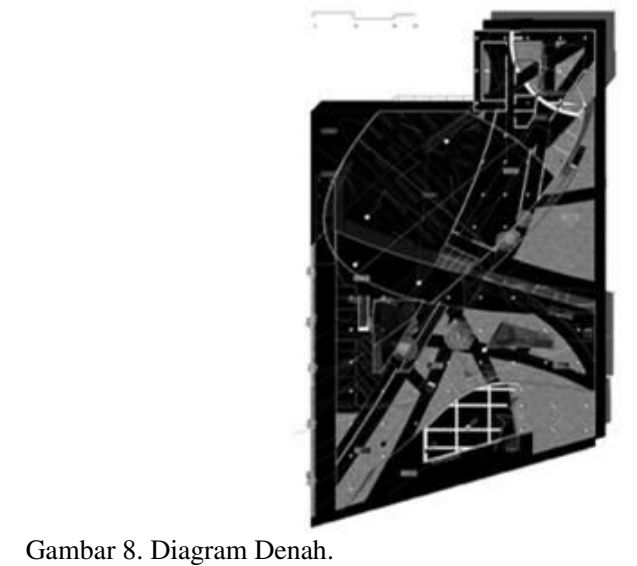

Gambar 9. Layoutplan.

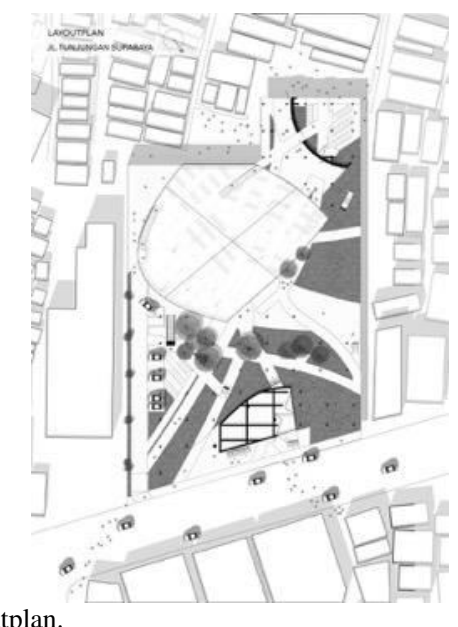

dengan garis hingga ditemukan titik temu dari garis. Titik Kesetaraan ini menggunakan praktek ilmu fisika bangunan yaitu titik berat. Dengan titik kesetaraan diharapkan mampu memberikan konsepsi titik awal untuk rancangan yang mampu menyelesaikan kriteria desain tentang kesetaraan lingkungan fisik dan sosial.

2. Transfer Analisa Aspek Non Fisik ke Aspek Fisik dalam Konteks: Proses ini adalah dengan melakukan analisa konteks menggunakan pendekatan behavior. Proses yang dilakukan adalah dengan menejermahkan esensi aspek non-fisik melalui pembacaan aspek fisik di kondisi lingkungan. Pada permasalahan ini, hal yang diamati adalah kepemilikan ruang dan keberagaman aktivitas pada lingkungan. Aspek fisik yang menjadi kesimpulan dari pengamatan tersebut adalah pergerakan dari asal keberadaan titik pada lingkungan yaitu kampung dan koridor Tunjungan.

3. Pergerakan Masyarakat Tunjungan sebagai Generatif Desain (Gambar 6): Proses metode ini adalah menggunakan konsepsi hasil analisa pergerakan masyarakat Tunjungan (Penduduk dan Non-Penduduk Tunjungan). Setelah analisa didapatkan, metode selanjutnya adalah dengan bantuan software "Rhino-Grashopper" [3] sebagai generator desain rancang. Garis berperan sebagai generator desain dari pergerakan manusia di konteks, Kemudian titik kesetaraan berperan sebagai "attractor" dalam desain. Kemudian hasil yang akan muncul adalah garis-garis implikasi pergerakan terhadap tapak rancang. Metode ini selain bertujuan untuk generator desain rancangan juga bertujuan sebagai pendukung 
tencapainya interaksi sosial dari kedua variabel (penduduk
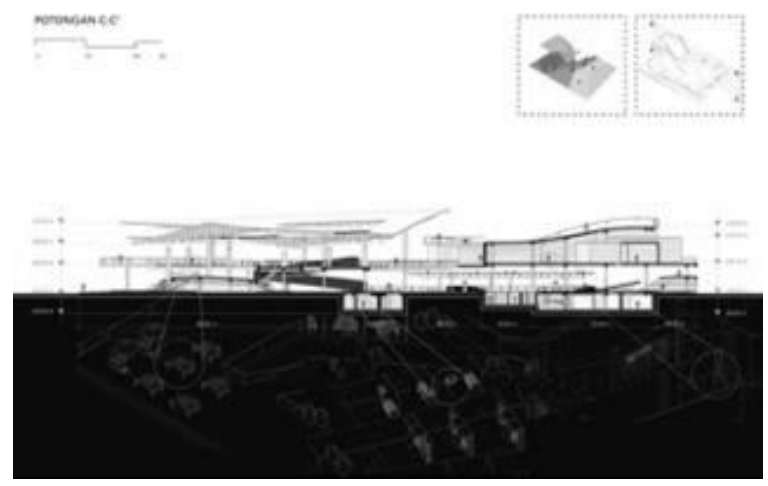

Gambar 13. Gambar Potongan.

4. Menyederhanakan Garis Implikasi Pergerakan Masyarakat Tunjungan (Gambar 7): Metode ini bersifat pengembangan generatif desain dan bersifat pengaturan desain. Langkah yang dilakukan adalah dengan memberikan pengaturan pada garis akibat pergerakan masyarakat Tunjungan. Garis yang diatur bertujuan untuk mengembangkan aspek formal untuk mendapatkan bentuk yang diinginkan tanpa menghilangkan esensi konsep dari pergerakan masyarakat Tunjungan sebagai generatif desain. Dengan metode ini, aspek formal akan lebih mudah diolah dan dikembangkan dalam proses desain selanjutnya.

5. Perletakan Program Berdasarkan Garis Pergerakan Masyarakat Tunjungan (Gambar 8): Metode ini adalah pengembangan dan pengaturan berdasarkan garis pergerakan masyarakat Tunjungan yang telah dihasilkan. Langkah yang digunakan adalah dengan mengidentifikasi permasalahan pada program dan aktivitas di konteks. Kesimpulan permasalahan pada program aktivitas di konteks adalah terdapat diferensial lingkungan fisik pada penduduk Tunjungan, maka dari itu program aktivitas yang dibutuhkan adalah solusi untuk menyetarakan kedua variabel, yaitu lingkungan fisik untuk wadah program penduduk Tunjungan. Langkah menyetarakan adalah mengatur dan mengembangkan sesuai permasalahan pada kedudukan dan kepemilikan koridor Tunjungan. Maka dari itu langkah yang digunakan adalah menggunakan pergerakan non-penduduk Tunjungan untuk letak program aktivitas penduduk Tunjungan.

6. Program dan Aktivitas Primer-Sekunder (Gambar 9): Metode ini adalah pengaturan program dan aktivitas yang sudah di rencanakan untuk di letakkan di dalam tapak rancangan. Program dan aktivitas akan diletakkan pada garis yang terbentuk oleh pergerakan masyarakat Tunjungan, dan garis implikasi dari radius attractor dari titik berat pada tapak rancangan. Garis dengan intensitas terbanyak akan digunakan sebagai wadah program dan aktivitas primer (merah), yaitu lapak berdagang atau pasar. Garis dari implikasi titik berat dengan intensitas terbanyak akan digunakan sebagai wadah program dan aktivitas primer-sekunder (biru), yaitu ruang pengolahan dagangan. Garis dengan intensitas terbanyak kedua akan digunakan sebagai wadah program dan aktivitas sekunder (kuning), yaitu sentra kuliner. Garis dari implikasi titik berat dengan intensitas terbanyak kedua akan digunakan sebagai wadah program aktivitas sekunder-tersier (hijau), yaitu ruang komunitas dan galeri seni.
Tunjungan dan non-penduduk Tunjungan).

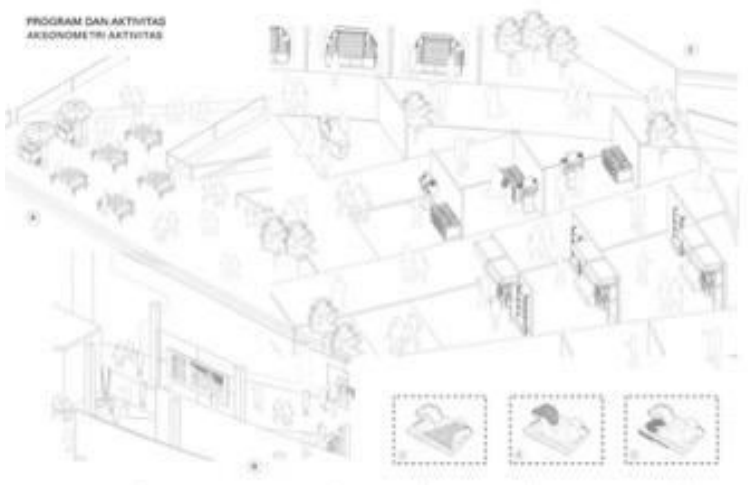

Gambar 14. Aksonometri Program dan Aktivitas.

7. Program dan Aktivitas Pendukung: metode ini adalah pengaturan program dan aktivitas berdasarkan kriteria ruang dan aktivitas-aktivitas pendukung yang membutuhkan wadah di konteks rancang. Metode ini dirancang dengan menjawab kriteria pada lingkungan fisik dan sosial yaitu aktivitas yang beragam serta fleksibel. Sehingga wadah program aktivitas untuk program pendukung merupakan ruang-ruang yang memang dirancang fleksibel dalam konteks waktu.

Elevasi Platform Berdasarkan Orientasi Lingkungan Fisik dan Sosial (Gambar 10): Metode ini adalah bertujuan untuk menyesuaikan elevasi platform berdasarkan orientasi pergerakan serta prefensi manusia dalam koridor Tunjungan. Dengan metode ini kesetaraan program dan aktivitas akan terpenuhi karena tidak ada lagi kesenjangan dalam hal intensitas subjek manusia yang berbeda dalam program aktivitas penduduk maupun non-penduduk Tunjungan. Selain itu, metode ini menggunakan maket model sebagai ilustrasi dan eksplorasi elevasi sesuai pengaturan yang ideal. Program dan aktivitas untuk non-penduduk Tunjungan, yaitu "Sentra Kuliner dan Taman" di atur agar non-penduduk mempunyai keinginan untuk mengunjungi bangunan. Kemudian ketika non-penduduk memasuki platform tersebut akan diberikan orientasi lanjutan yaitu "Pasar atau Lahan Perdagangan", yang merupakan program dan aktivitas untuk penduduk Tunjungan. Dengan cara tersebut maka tidak ada lagi diferensial lingkungan fisik dan sosial dalam koridor Tunjungan".

\section{HASIL DAN EKSPLORASI}

Hal utama dalam hasil dan eksplorasi pada rancangan ini adalah bagaimana kesetaraan program arsitektur terbemtuk dari aktivitas manusia di konteks lingkungan fisik dan nonfisik. Sehingga diagram denah adalah hasil dari semua program arsitektur berdasarkan keberagaman dan permasalahan pada aktivitas manusia di konteks Koridor Tunjungan (Gambar 11).

\section{a. Denah}

Konsep besar dari rancangan denah adalah pada platform dasar atau sejajar dengan jalan raya Tunjungan. Denah pada ketinggian tersebut merupakan pengembangan dan pengaturan pada konsep besar desain yaitu "Equality and Nosegmentation. Kesetaraan yang didapat dari denah lantai tersebut adalah sebuah pengembangan dari pergerakan masyarakat Tunjungan, yang diatur dengan 


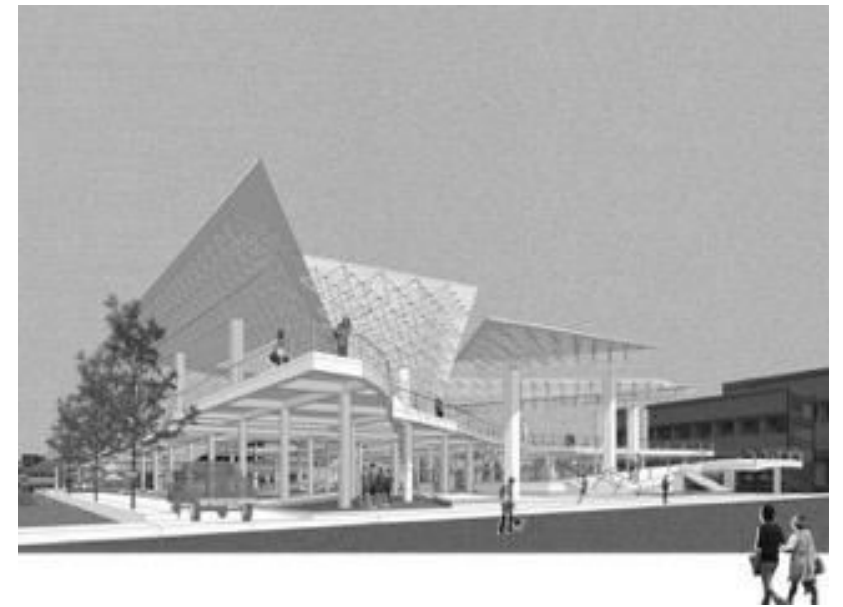

Gambar 12. Ilustrasi Bangunan.

mempertimbangkan prefensi, aktivitas, dan gaya hidup subjek antara penduduk dan non-penduduk Tunjungan. Begitu juga dengan Anti-Segmentasi, pada lantai tersebut denah didesain supaya memiliki keterbukaan yang maximal. Selain itu menjadi katalis atau penghubung antara koridor Tunjungan dengan kampung Tunjungan (Gambar 11).

b. Layoutplan

Gambar Layoutplan (Gambar 12) adalah gambar layoutplan berdasarkan tujuan desain yang diinginkan. Rancangan arsitektur menjadi katalis dan jembatan antara koridor dan kampung Tunjungan. Sehingga tidak ada lagi batas fisik antara kedua variabel penduduk dan non-penduduk Tunjungan. Sehingga kesetaraan yang terjadi pada kondisi tersebut adalah katalis antara kebutuhan aktivitas manusia pada kedua variabel yang memiliki masalah pada konteks Koridor Tunjungan.

\section{c. Potongan}

Pada gambar diatas dapat dijelaskan bahwa rancangan potongan mempertimbangkan konsep elevasi berdasarkan orientasi konteks, dan keterhubungan antar program aktivitas bangunan. Dalam pengembangan konsep orientasi berdasarkan konteks pada rancangan potongan bertujuan untuk memberikan keterbukaan yang maksimal, dan tidak ada lagi batas fisik antara koridor dan kampung Tunjungan. Sehingga pengembangan dan pengaturan pada rancangan potongan akan memberikan kesetaraan pada prefensi, aktivitas, dan gaya hidup yang berbeda pada kedua variabel penduduk dan non-penduduk Tunjungan (Gambar 13).

d. Ilustrasi Program

Pada gambar diatas dapat dijelaskan bahwa program dan aktivitas yang terjadi adalah hasil dari eksekusi pengembangan dan pengaturan konsep kesetaraan dan anti-segmentasi. Ilustrasi tersebut adalah merepresentasikan keterhubungan antar program. Program primer, sekunder, dan pendukung seharusnya memiliki batas sendiri-sendiri namun tetap terhubung satu sama lain. Sehingga tidak ada segmentasi yang terjadi antara kedua variabel penduduk dan non-penduduk Tunjungan (Gambar 14).

sebuah hal yang bisa mewakili segala masalah pada konteks. Dengan begitu semua konsep denah, tampak, potongan dan lainnya merupakan pengembangan dan pengaturan pergerakan masyarakat Tunjungan. Rancangan program arsitektur ini mampu memberikan kesetaraan dalam lingkungan fisik dan sosial. Rancangan program arsitektur tersebut adalah rancangan arsitektur yang berhasil menerima perbedaan prefensi, aktivitas, dan gaya hidup manusia di koridor tunjungan dalam aspek fisik maupun non-fisik dalam suatu konteks (Gambar 15).

\section{KESIMPULAN}

Dalam perancangan ini, hal yang menjadi dasar desain adalah pergerakan masyarakat itu sendiri.

\section{DAFTAR PUSTAKA}

[1] S. Wimbarti, "Life Style dari sudut pandang Psikologi dikaitkan dengan perilaku dan lingkungan (arsitektur dan perkotaan)," Yogyakarta, 2013.

[2] P. Schumacher, The Autopoiesis Of Architecture: A New Framework for Architecture. London: Wile, 2011.

[3] P. Eisenman, Diagram Diaries. New York: Universe, 1999. 